\title{
TWO-PHASE PARTITIONING OF A COLLAGENASE PRODUCED BY YEAST (13II) ISOLATED FROM BEE POLLEN (Melípona spp.)
}

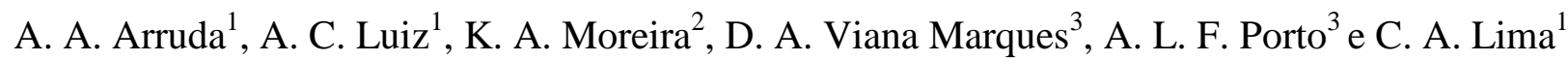 \\ ${ }^{1}$ Universidade de Pernambuco, Campus Garanhuns \\ ${ }^{2}$ Universidade Federal Rural de Pernambuco, Campus Garanhuns \\ ${ }^{3}$ Universidade Federal Rural de Pernambuco, Departamento de Morfologia e Fisiologia Animal \\ carolaalbuquerque18@hotmail.com
}

\begin{abstract}
RESUMO - The potential application of aqueous two-phase systems of PEG/phosphate to recovery collagenase from yeast (13II) fermentation broth was investigated. To plan the experimental tests and evaluate the corresponding results, a $2^{4}$ full factorial design was employed, for which PEG molar mass $\left(\mathrm{M}_{\mathrm{PEG}}\right)$, PEG concentration $\left(\mathrm{C}_{\mathrm{PEG}}\right)$, phosphate concentration $\left(\mathrm{C}_{\mathrm{PHOS}}\right)$ and the $\mathrm{pH}$ were selected as independent variables, while the purification factor $(\mathrm{PF})$, the partition coefficient $(\mathrm{K})$ and the activity yield $(\mathrm{Y})$ were selected as responses. The analysis of the $2^{4}$ full factorial design data indicated that $\mathrm{PF}, \mathrm{K}$ and $\mathrm{Y}$ of collagenase in the top phase was shown to increase with increasing $\mathrm{C}_{\mathrm{PEG}}$ and $\mathrm{C}_{\mathrm{PHOS}}$ and decreasing $\mathrm{pH}$. The highest PF (2.83) was present in the top phase of the system composed by $8000 \mathrm{~g} / \mathrm{mol} \mathrm{M}_{\mathrm{PEG}}, 17.5 \%$ (w/w) $\mathrm{C}_{\mathrm{PEG}}, 15 \%$ (w/w) $\mathrm{C}_{\mathrm{PHOS}}$ and $\mathrm{pH}$ 6.0. According to these results, the ATPS seems to be an interesting alternative for primary step purification of colagenase from fermentation broth.
\end{abstract}

\section{INTRODUCTION}

Microbial collagenases have received special attention in medicine and biotechnology, because of their ability to hydrolyze the native and denatured triple helix of collagen to small fragments; therefore, they have been widely used in food, pharmaceutical, cosmetic and leather industries (Hamdy, 2008), among others.

Such a variety of applications requires increasing amounts of highly pure collagenase. So far, collagenases have been purified by traditional methods combining operations like centrifugation, precipitation with ammonium sulfate, ultrafiltration, successive chromatographic steps, dialysis and final concentration of the product (Sakurai et al., 2009; Wu et al., 2011). However, these operations are time-consuming and difficult to scale up, require some expensive reagents, thus contributing to raise the cost of downstream processing, and increase macromolecular unfolding, leading to biological activity loss and poor yield for the overall process (Imelio et al., 2008).

Partitioning in aqueous two-phase systems (ATPS) are a promising alternative methods to separate and purify protein mixtures. Removal of contaminants by ATPS is relatively simple and cheap, and can be applied directly in a homogenate to recover a natural or genetically modified product (Jara e Pilosof, 2011). ATPS consist of two liquid phases that are immiscible beyond a 
critical concentration: a top phase rich in one polymer (polyethylene glycol, dextran, etc.) and a bottom aqueous phase rich in another incompatible polymer or a salt (phosphate, citrate, sulfate, etc.). For industrial purposes, polymer-salt systems have been preferred due to the low cost of the phase-forming chemicals. These systems are also attractive because of their rapid phase disengagement and the availability of commercial separations, which allow a faster and continuous protein separation (Túbio et al., 2009).

The aim of this work was to extract/concentrate directly from the fermented broth the collagenase produced by yeast (13II) by PEG/phosphate ATPS. For this purpose, a $2^{4}$-full factorial design was applied to the process to identify the optimal levels of PEG molar mass, $\mathrm{pH}$, phosphate and PEG concentrations.

\section{MATERIALS AND METHODS}

\subsection{Microorganism and culture conditions}

The yeast used in this study was isolate from bee pollen (Melípona spp.). The yeast (13II) was maintained at $4{ }^{\circ} \mathrm{C}$ on Sabouraud dextrose Agar slants. The culture medium described by Nickerson e Mohan (1953), composed of $1.0 \%$ (w/v) gelatin, $0.025 \mathrm{~g} / \mathrm{L} \mathrm{MgSO}_{4} .7 \mathrm{H}_{2} \mathrm{O}, 1.5 \mathrm{~g} / \mathrm{L}$ $\mathrm{K}_{2} \mathrm{HPO}_{4}, 0.015 \mathrm{~g} / \mathrm{L} \mathrm{FeSO}_{4} .7 \mathrm{H}_{2} \mathrm{O}, 0.025 \mathrm{CaCl}_{2}, 0.005 \mathrm{~g} / \mathrm{L} \mathrm{ZnSO}_{4} .7 \mathrm{H}_{2} \mathrm{O}, \mathrm{pH} 6,5$, was used for collagenase production.

\subsection{Collagenase production}

Collagenase was obtained from a culture supernatant as follows. The strain was sub-cultured on Sabouraud medium, $\mathrm{pH} 6.5$, incubated at $30^{\circ} \mathrm{C}$ for $24 \mathrm{~h}$ and a calibrated cellular suspension $\left(A 600=0.1\right.$, corresponding to an average cell concentration of $10^{6}$ cells $\left./ \mathrm{ml}\right)$ was used to inoculate a $250 \mathrm{ml}$ Erlenmeyer flask containing $50 \mathrm{ml}$ of culture medium and grown for $72 \mathrm{~h}$ at $30{ }^{\circ} \mathrm{C}$ in an orbital incubator shaker with $150 \mathrm{rpm}$. The broth obtained at the end of fermentation $(72 \mathrm{~h})$ was centrifuged at $15,000 \times \mathrm{g}$ and $4{ }^{\circ} \mathrm{C}$ for $20 \mathrm{~min}$ to remove the cells. Since the target collagenase was an extracellular one, the supernatant was analyzed to determine the final protein concentration and collagenase activity and used as an enzyme source (referred to as the crude extract). All the collagenase purification experiments were made on the crude extract.

\subsection{Preparation of aqueous two-phase systems}

A $40 \%(\mathrm{w} / \mathrm{w})$ phosphate solution was prepared at room temperature $\left(25 \pm 1{ }^{\circ} \mathrm{C}\right)$ by mixing the amounts of dibasic and monobasic sodium phosphates needed to reach the desired $\mathrm{pH}$. The required amounts of this solution were mixed with $50 \%(\mathrm{w} / \mathrm{w})$ PEG solutions with different molar masses, specifically 1500,4000 and $8000 \mathrm{~g} / \mathrm{mol}$. These solutions were then added to $15 \mathrm{~mL}$ graduated tubes. Aliquots of the fermented broth corresponding to $20 \%(\mathrm{w} / \mathrm{w})$ of the total mass were later added, along with enough water to give a $10 \mathrm{~g}$ system. After $1.0 \mathrm{~min}$ vortex shaking, the two phases were left to separate by settling for $120 \mathrm{~min}$. The phase volumes were then measured, and the protein concentration and collagenase activity were determined in each phase. To avoid any PEG or phosphate interference, all the samples were analyzed against protein-free standard solutions having the same phase composition. 


\subsection{Azocoll assay for collagenase activity determination}

The Azo dye impregnated collagen-Azocoll (Sigma Chemical Co., St Louis, MO) assay was carried out according to the method developed by Chavira et al. (1984).

\subsection{Protein determination}

Protein concentration was determined according to Smith et al. (1985), using bovine serum albumin as standard.

\subsection{Experimental design and statistical analysis}

A two-level full factorial design $\left(2^{4}\right)$ was carried out to study the effects and interactions of PEG molar mass $\left(\mathrm{M}_{\mathrm{PEG}}\right)$, PEG concentration $\left(\mathrm{C}_{\mathrm{PEG}}\right)$, phosphate concentration $\left(\mathrm{C}_{\mathrm{PHOS}}\right)$ and $\mathrm{pH}$ on collagenase partition/purification by ATPS. Experiments were carried out at all combinations of the levels given in Table 1. The central point was run in quadruplicate, to provide an estimate of the pure error variance of the experimental responses, namely the collagenase purification factor $(\mathrm{PF})$, partition coefficient $(\mathrm{K})$ and activity yield (Y). Experimental errors of the effects were estimated and used to assess the significance of the main effects and interactions of the four independent variables on the responses. The goodness-of-fit of the full $2^{4}$-model was evaluated by the analysis of variance, from which the statistical significance of each effect, at the 95\% confidence level ( $\mathrm{p}<0.05)$, was determined. All statistical and graphical analyses were carried out by the Statistica 8.0 software (StatSoft Inc., Tulsa, OK, USA).

Table 1 - Factor levels of the $2^{4}$-full factorial design used to investigate collagenase partition and purification by ATPS.

\begin{tabular}{lccc}
\hline \multicolumn{1}{c}{ Factor } & Low $(-1)$ & $\begin{array}{c}\text { Level } \\
\text { Center }(0)\end{array}$ & High $(+1)$ \\
\hline PEG molar mass $\left(\mathrm{M}_{\mathrm{PEG}}\right)$ & 1500 & 4000 & 8000 \\
PEG concentration $\left(\mathrm{C}_{\mathrm{PEG}}\right)$ & 12.5 & 15.0 & 17.5 \\
Phosphate concentration $\left(\mathrm{C}_{\mathrm{PHOS}}\right)$ & 10.0 & 12.5 & 15.0 \\
$\mathrm{pH}$ & 6.0 & 7.0 & 8.0 \\
\hline
\end{tabular}

\subsection{Determination of partition coefficient, activity yield and purification factor}

The collagenase partition coefficient was determined as the ratio of the collagenase activity in the top phase (AT) to that in the bottom phase (AB).

The activity yield was defined as the ratio of AT to the initial activity in the fermentation broth (AF) and expressed as a percentage.

The purification factor was calculated as the ratio of the specific activity in the top phase (AT/CT) to the initial specific activity in the fermentation broth before partition (AF/CF), where $\mathrm{CT}$ and $\mathrm{CF}$ are the protein concentrations, expressed in $\mathrm{mg} / \mathrm{mL}$, in the top phase and the fermentation broth, respectively. 


\section{RESULTS AND DISCUSSION}

The conditions and results of the design experiments are shown in Table 2. Run 5 did not form any biphasic system, because the component complexity of the fermentation medium led to a deviation towards the monophasic region of the binodal curve.

Table 2 - Level combinations and results of the extraction of collagenase from yeast (13 II) by PEG/phosphate ATPS according to the $2^{4}$ experimental design

\begin{tabular}{cccccccc}
\hline Run & $\begin{array}{c}\mathbf{M}_{\text {PEG }} \\
(\mathbf{g} / \mathbf{m o l})\end{array}$ & $\begin{array}{c}\mathbf{C}_{\text {PEG }} \mathbf{\%} \\
(\mathbf{w} / \mathbf{w})\end{array}$ & $\mathbf{p H}$ & $\begin{array}{c}\mathbf{C}_{\mathbf{P H O S}} \mathbf{\%} \\
(\mathbf{w} / \mathbf{w})\end{array}$ & $\mathbf{Y \%}$ & $\mathbf{P F}$ & $\mathbf{K}$ \\
\hline $\mathbf{1}$ & 1500 & 12.5 & 6 & 10 & 76.33 & 1.83 & 2.31 \\
$\mathbf{2}$ & 8000 & 12.5 & 6 & 10 & 39.015 & 1.22 & 0.59 \\
$\mathbf{3}$ & 1500 & 17.5 & 6 & 10 & 83.39 & 1.46 & 5.09 \\
$\mathbf{4}$ & 8000 & 17.5 & 6 & 10 & 29.09 & 0.59 & 0.43 \\
$\mathbf{5}$ & 1500 & 12.5 & 8 & 10 & - & - & - \\
$\mathbf{6}$ & 8000 & 12.5 & 8 & 10 & 49.86 & 1.08 & 1.92 \\
$\mathbf{7}$ & 1500 & 17.5 & 8 & 10 & 82.05 & 1.14 & 2.61 \\
$\mathbf{8}$ & 8000 & 17.5 & 8 & 10 & 49.43 & 1.04 & 3.16 \\
$\mathbf{9}$ & 1500 & 12.5 & 6 & 15 & 32.78 & 0.69 & 4.26 \\
$\mathbf{1 0}$ & 8000 & 12.5 & 6 & 15 & 62.28 & 2.08 & 4.30 \\
$\mathbf{1 1}$ & 1500 & 17.5 & 6 & 15 & 62.00 & 1.36 & 14.07 \\
$\mathbf{1 2}$ & $\mathbf{8 0 0 0}$ & $\mathbf{1 7 . 5}$ & $\mathbf{6}$ & $\mathbf{1 5}$ & $\mathbf{9 0 . 8 8}$ & $\mathbf{2 . 8 3}$ & $\mathbf{1 6 . 5 2}$ \\
$\mathbf{1 3}$ & 1500 & 12.5 & 8 & 15 & 46.20 & 1.03 & 6.56 \\
$\mathbf{1 4}$ & 8000 & 12.5 & 8 & 15 & 59.51 & 1.53 & 3.36 \\
$\mathbf{1 5}$ & 1500 & 17.5 & 8 & 15 & 88.99 & 1.38 & 13.31 \\
$\mathbf{1 6}$ & 8000 & 17.5 & 8 & 15 & 45.28 & 1.12 & 5.90 \\
$\mathbf{1 7}$ & 4000 & 15 & 7 & 12.5 & 55.67 & 1.05 & 1.61 \\
$\mathbf{1 8}$ & 4000 & 15 & 7 & 12.5 & 50.36 & 0.91 & 1.51 \\
$\mathbf{1 9}$ & 4000 & 15 & 7 & 12.5 & 53.48 & 0.98 & 1.51 \\
$\mathbf{2 0}$ & 4000 & 15 & 7 & 12.5 & 55.63 & 0.93 & 1.05 \\
\hline
\end{tabular}

\subsection{Effects on the partition coefficient}

The partition coefficient, $\mathrm{K}$, is often used to evaluate the extension of biomolecules separation in aqueous two-phase polymeric systems. When $\mathrm{K}$ is significantly distinct for the target biomolecule and for other biomolecules present in the system, the extraction is more successful. In other words, $\mathrm{K}$ values larger than unity indicate the partitioning effectiveness of the aqueous twophase system (Mazzola et al., 2008). All four factors have significant main effects on the partition coefficient $(\mathrm{K})$. There are also several significant interactions 1-2, 1-3, 1-4, 2-3, 2-4 and 3-4, which means that the effect of a given factor depends on the levels of the other factors (Table 3 ). In particular, $\mathrm{C}_{\mathrm{PHOS}}(4)$ has the largest effect on $\mathrm{K}$. Since this effect is positive levels correspond to higher $\mathrm{C}_{\mathrm{PHOS}}$ higher $\mathrm{K}$ value's on average. This can be ascribed to the "salting out" effect. As the salt concentration increases, the solubility of biomolecules in the salt rich (bottom) phase 
decreases, which results in increased partitioning of biomolecules to the top phase (Babu et al., 2008).

$\mathrm{K}$ was also positively influenced by an increase in $\mathrm{C}_{\mathrm{PEG}}(2)$. As the $\mathrm{C}_{\mathrm{PEG}}$ increases, the number of polymer units involved in the bio-molecular partitioning also increases and more protein molecules partition into the PEG phase due to hydrophobic interaction between the protein and PEG (Saravanan et al., 2008). On the other hand, $\mathrm{K}$ was negatively influenced by both $\mathrm{M}_{\mathrm{PEG}}$ (1) and $\mathrm{pH}$ (3) on average. $\mathrm{M}_{\mathrm{PEG}}=1500 \mathrm{~g} / \mathrm{mol}$ resulted in more collagenase partitioning to the top phase than either $M_{P E G}=4000 \mathrm{~g} / \mathrm{mol}$ or $8000 \mathrm{~g} / \mathrm{mol}$. The increase of the $M_{P E G}$ results in less available space for collagenase in the top phase, which leads to a decrease in the partition coefficient (Araújo et al. 2011).

\subsection{Effects on the activity yield}

Higher average collagenase activity yields are associated with higher $\mathrm{C}_{\mathrm{PEG}}$ and lower $\mathrm{M}_{\mathrm{PEG}}$ levels (Table 3). A possible explanation is that an increase in solvent viscosity considerably decreases enzymatic catalytic rate, as already observed for carboxypeptidase, trypsin and catalase, as well as collagenase (Araújo et al., 2011). In the present study, exception occurred in run 12, for which PEG molar mass was 8000 (Table 2). In this case, since the $\mathrm{C}_{\mathrm{PHOS}}$ was $15 \%(\mathrm{w} / \mathrm{w})$, salting out apparently prevailed over volume exclusion leading to more collagenase partitioning to the top phase, resulting in high activity yields.

As for the partition coefficient, the main effect of $\mathrm{C}_{\mathrm{PHOS}}$ was significantly positive while $\mathrm{pH}$ showed a significantly negative effect. So the conditions ensuring the highest values of activity yield were those in which the $\mathrm{M}_{\mathrm{PEG}}$ was low and the $\mathrm{C}_{\mathrm{PEG}}$ and $\mathrm{C}_{\mathrm{PHOS}}$ were high (Table 2 and Table 3).

Table 3 - Statistically significant effect estimates $(\mathrm{p}<0.05)$ determined for the responses given in Table 1. Single digits indicate main effects; digit combinations stand for two-factor interaction effects. Notation as in Table 1

\begin{tabular}{lccc}
\hline Effect & PF & Y & K \\
\hline $\mathbf{1}\left(\mathrm{M}_{\mathrm{PEG}}\right)$ & 10.41 & -4.63 & -11.97 \\
$\mathbf{2}\left(\mathrm{C}_{\mathrm{PEG}}\right)$ & 5.85 & 16.49 & 37.61 \\
$\mathbf{3}(\mathrm{pH})$ & -14.98 & -5.44 & -10.70 \\
$\mathbf{4}\left(\mathrm{C}_{\mathrm{PHOS}}\right)$ & 14.66 & 7.86 & 51.93 \\
$\mathbf{1 2}$ & -8.49 & -15.69 & -6.08 \\
$\mathbf{1 3}$ & ---- & ---- & -4.23 \\
$\mathbf{1 4}$ & 14.42 & 10.22 & -4.19 \\
$\mathbf{2 3}$ & ----- & 5.51 & -11.45 \\
$\mathbf{2 4}$ & 5.04 & ---- & 24.63 \\
$\mathbf{3 4}$ & ----- & 3.84 & -9.24 \\
\hline
\end{tabular}

\subsection{Effects on the purification factor}

The results for the partition coefficient and activity yield are of course not negligible, but the purification factor (PF) is considered a far more important response for this study, because the collagenase is being purified for clinical and therapeutic applications. 
Considering first the $\mathrm{M}_{\mathrm{PEG}}$ effect, it is clear that the negative effect means that decreasing $\mathrm{M}_{\mathrm{PEG}}$ is likely to improve purification (Table 3).

It is important to note that $\mathrm{pH}$ was responsible for the greatest effects on purification factor in the top phase (Table 3). $\mathrm{C}_{\mathrm{PHOS}}$ also exerted an important influence on the purification of the collagenase, the effect of this variable was only lower than the effect of $\mathrm{pH}$. This variable showed significant positive effect, suggesting that an increase in this parameter values would improve collagenase purification to the top phase.

The positive significant effect observed for $\mathrm{M}_{\mathrm{PEG}}$ and $\mathrm{C}_{\mathrm{PEG}}$ means that higher purification factors are associated with higher values of theses parameters. According to these results, therefore, higher $\mathrm{PF}$ are expected at more acidic $\mathrm{pH}$ values, together with increased phosfate and PEG concentration and increased PEG molar mass (Table 3). As a result of these factor combinations $\left(8000 \mathrm{~g} / \mathrm{mol} \mathrm{M}_{\mathrm{PEG}}, 17.5 \%(\mathrm{w} / \mathrm{w}) \mathrm{C}_{\mathrm{PEG}}, 15 \%(\mathrm{w} / \mathrm{w}) \mathrm{C}_{\mathrm{PHOS}}\right.$ and $\mathrm{pH} 6.0$ ), corresponding to run 12 , was achieved the best conditions for the purification factor $(\mathrm{PF}=$ 2.83) (Table 2).

\section{CONCLUSIONS}

This paper reports a simplified strategy using PEG-phosphate aqueous two phase system as a first step for the potential purification of a collagenase from yeast (13II) fermentation broth. The experimental models studied suggested that collagenase could be readily extracted and purified from fermentation broth. $\mathrm{C}_{\mathrm{PEG}}$ and $\mathrm{C}_{\mathrm{PHOS}}$ had positive main effects, and the $\mathrm{pH}$ had a negative effect on all responses. Selected systems could allow differential partitioning between target enzyme and contaminants and the highest PF (2.283) occurred as a result of these factor combinations $\left(8000 \mathrm{~g} / \mathrm{mol} \mathrm{M}_{\mathrm{PEG}}, 17.5 \%(\mathrm{w} / \mathrm{w}) \mathrm{C}_{\mathrm{PEG}}, 15 \%\right.$ (w/w) $\mathrm{C}_{\mathrm{PHOS}}$ and $\mathrm{pH} 6.0$ ).

\section{REFERENCES}

ARAÚJO, R.F.F.; PORTO, T.S.; MARTINS, D.B.G.; DUTRA, R.F., PORTO, A.L.F., LIMA-FILHO, J.L. Partitioning of lactate dehydrogenase from bovine heart crude extract by polyethylene glycol-citrate aqueous two-phase systems. Fluid Phase Equilib., v. 301, p. 46-50, 2011.

BABU, B.R.; RASTOGI, N.K.; RAGHAVARAO, K.S.M.S. Liquid-liquid extraction of bromelain and polyphenol oxidase using aqueous two-phase syste. Chem. Eng. Process., v. 47, p. 83-89, 2008.

CHAVIRA, R.J.; BURNETT, T.J.; HAGEMAN, J.H. Assaying proteinases with azocoll. Anal Biochem. v. 136, p. 4446-4450, 1984.

HAMDY, H.S.. Extracellular collagenase from Rhizoctonia solani: production, purification and characterization. Indian J. Biotechnol., v. 7, p. 333-340, 2008.

IMELIO, N.; MARINI, A.; SPELZINI, D.; PICÓ, G.; FARRUGGIA, B. Pepsin extraction from bovine stomach using aqueous two-phase systems: Molecular mechanism and 
influence of homogenate mass and phase volume ratio. J. Chromatogr. B., v. 873, p. 133-138, 2008.

JARA, F.; PILOSOF, A.M.R. Partitioning of $\alpha$-lactalbumin and $\beta$-lactoglobulin in whey protein concentrate/hydroxypropylmethylcellulose aqueous two-phase systems. Food Hydrocolloid. v. 25, p. 374-380, 2011.

NICKERSON, W.J.; MOHAN, R.R. Studies on the nutrition and metabolism of Streptomyces. In: Symposium on Actinomycetales, International Comgress of Microbiology, $6^{\circ}$ Congress, Roma, p. 137-146, 1953.

SAKURAI, Y.; INOUE, H.; NISHII, W.; TAKAHASHI, T.; LINO, Y.; YAMAMOTO, M.; TAKAHASHI, K. Purification and characterization of a major collagenase from Streptomyces parvulus. Biosci. Biotechnol. Biochem., v. 73, p. 21-28, 2009.

SARAVANAN, S.; RAO, J.R.; NAIR, B.U.; RAMASAMI, T. Aqueous two-phase poly(ethylene glycol)-poly(acrylic acid) system for protein partitioning: Influence of molecular weight, pH and temperature. Process Biochem., v. 43, p. 905-911, 2008.

SMITH, P.K.; KROHN, R.I.; HERMANSON, G.T.; MALLIA, A.K.; GARDENER, F.H.; PREVENANO, M.D.,; FUJIMOTO, C.K.; GOEKE, N.M.; OLSON, B.J.; KLENK, D.C. Measurement of protein using bicinchoninic acid. Anal Biochem., v. 150, p. 76-85, 1985.

TUBIO, G.; PICÓ, G.A.; NERLI, B.B. Extraction of trypsin from bovine pancreas by applying polyethyleneglycol/sodium citrate aqueous two-phase systems. J. Chromatogr. B., v. 877, p. 115-120, 2009.

WU, Q.; LI, C.; CHEN, H.; SHULIANG, L. Purification and characterization of a novel collagenase from Bacillus pumilus Col-J. Appl. Biochem. Biotechnol., v. 160, p. 129$139,2010$. 